\title{
Exploring Students' Affixation Error on Writing Hortatory Exposition Essay
}

\author{
Reni Putri Gemini ${ }^{1}$, Hermawati Syarif ${ }^{2}$, and Hamzah $^{3}$ \\ ${ }^{1}$ Universitas Negeri Padang, Padang, Indonesia, $\triangle$ (email), reniputrigemini@yahoo.com \\ ${ }^{2}$ Universitas Negeri Padang, Padang, Indonesia, $\triangle$ (email), hermawati_sy@fbs.unp.ac.id \\ ${ }^{3}$ Universitas Negeri Padang, Padang, Indonesia, $\square$ (email), zzahham@gmail.com
}

\begin{abstract}
This research aimed to pinpoint affixation errors in writing, which was done by extracting the errors in the writings of 30 hortatory exposition essays written by students of English Education Department at Universitas Negeri Padang. This study was using Plag's (2003) theory of affixation and McCarthy's (2002) theory. As a result of this qualitative research which was using content analysis method, two types of errors were extracted as the following: 196 inflectional suffixes errors and 93 derivational suffixes errors. For inflectional suffixes, there were 53 errors in showing present tense, 14 errors in showing past tense, 8 errors in showing participle, 14 errors in showing continuous, 102 errors in showing plurality, and 5 errors in showing possession. For derivational suffixes, there were 85 errors in the use of noun, 7 errors in the use of the adjectives, and 1 error in the use of adverb. However, it can be generally concluded that the University students have not mastered or understood the structure of English language. The findings of the study have implications for the academic writing class.
\end{abstract}

\section{Keywords: Affixation Error, Hortatory Exposition Essay}

\section{INTRODUCTION}

Among four language skills which are usually taught in the process of learning (speaking, reading, listening and writing), writing is commonly seen as the most difficult skill to comprehend (Hogue, 2003). This opinion is a common perspective since teaching writing is not simply a matter of writing things down. A great deal of working ideas in which they are being organized needs to be considered. These ideas are necessary to be arranged and developed in a well-structured organization using appropriate vocabulary, spelling and also grammar. It is clear that writing needs to be as accurate as it should be due to its process which includes making the sentences and paragraphs coherence and cohesion with correct spelling, proper punctuation and other features.

Beside of the complexity of writing, composition of words or the grammar rule are the elements that make most of students have difficulty to write. To make words in English especially in writing, the processes are varied such as compounding, blending, affixation and so on. Nevertheless, to avoid minor errors in making words grammatically correct in writing, students may learn about study of words to comprehend the morphological awareness. Moreover, Carstairs \& McCarthy (2002:16) declare that morphology deals with area of grammar involving the morphemes concerned with the structure of words. It is widely known as a study of word formation.

Affixation as one of the main elements in morphology cannot be separated with writing. In addition,
Bowers \& Cooke (2012) mention that morphology is identified as foundational to the writing system. So, each student who does not understand part of words in grammatical way means he/she is not completely prepared to understand about how the writing system works. In other word, to make a good writing, you have to understand morphology as it is closely related to the structure of words.

So, due to the difficulty to making words in writing, affixation becomes important because people use affixes to convey meaning when they write. When someone writes, he needs to think about the affixation in words. Another reason affixation is important is because it helps students identify and understand difficult academic vocabulary.

Affixation which is frequently used can lead them to problems in essay writing of students at Universitas Negeri Padang. These problems obviously will cause the reoccurring of errors and mistakes. Moreover, knowledge of affixes can be used to increase writing skills especially in Universitas Negeri Padang. Further investigation about affixation is needed to study since the previous studies did not analyze errors in affixation in students' writing at university level. It will give an insight for better learning by investigating errors that usually made by students in their writing.

The knowledge of affixation which is accommodated through grammar class will help students to create new words and enable them to increase their 
quality of writing. Universitas Negeri Padang has a set of grammar courses from 1 st to 5 th semester for undergraduate program. The reason the researcher chose the 3rd semester students because they have taken Intensive Course, Basic Grammar and Intermediate Grammar which is sufficient for this research. Hortatory exposition essay was chosen as the type of essay being analyzed since it is learned by English Education Department students and conducted by using various language features which accommodate numerous affixes necessary for this research.

\section{METHOD}

The data in this research are words or sentences containing errors in the use of affixation. The data are 30 hortatory exposition essay of English Education Department students at Universitas Negeri Padang. The research uses the qualitative approach with content analysis method. Data selection incorporates the purposive sampling technique. Data collection in this research is conducted by the researchers directly. The research steps consist of seven stages. There are (1) collecting students' essays, (2) selecting and assigning 30 papers as data source, (3) rereading the essays, (4) underlining the errors, (5) inserting the data into the analysis table, (6) recapitulating the number of errors, and (7) analyzing the data. Then, this research uses interactive model data analysis through three stages. Those are data reduction, data presentation, as well as conclusion and verification.

\section{RESULT AND DISCUSSION}

The affixation errors classifications made by students can be seen in Table 1 . There are 289 errors found in the use of affixation include 196 errors in inflectional suffixes and 93 errors in derivational suffixes.

Table 1. Affixation Errors Classification

\begin{tabular}{ccc}
\hline No & Types & $\begin{array}{c}\text { Numbers of } \\
\text { Errors }\end{array}$ \\
\hline $\mathbf{1}$ & Derivational Prefixes & - \\
\hline $\mathbf{2}$ & Inflectional Suffixes & 196 \\
\hline $\mathbf{3}$ & Derivational Suffixes & 93 \\
\hline & Total of Errors & $\mathbf{2 8 9}$ \\
\hline
\end{tabular}

Next, from these three categories, the derivation errors were divided into four classifications and the inflectional errors were divided into seven classifications. The derivational prefixes errors made by the students can be seen in Table 2 .

Table 2. Inflectional Suffixes Errors Classification

\begin{tabular}{cccc}
\hline No & Sub-Indicators & Affixes & $\begin{array}{c}\text { Numbers of } \\
\text { Errors }\end{array}$ \\
\hline $\mathbf{1}$ & Present Tense & -s/-es & 53 \\
\hline $\mathbf{2}$ & Past Tense & -ed & 14 \\
\hline $\mathbf{3}$ & Participle & -ed/-en & 8 \\
\hline $\mathbf{4}$ & Continuous Tense & -ing & 14 \\
\hline $\mathbf{5}$ & Plural & -s/-es & 102 \\
\hline $\mathbf{6}$ & Possession & -'s/-' & 5 \\
\hline
\end{tabular}

\begin{tabular}{clcc}
\hline $\mathbf{7}$ & Comparison & -er/-est & - \\
\hline & Total & & $\mathbf{1 9 6}$ \\
\hline
\end{tabular}

First, errors of inflectional suffixes were occurred in addition, omission, and misformation. The examples are shown as follows.

1.1. In short, social networking sites also gives negative impact for us

1.2. It is also being teached in every country.

1.3. It's really help us in communication.

1.4. Find many informations and many others

1.5. Still it is users responsibilities for being careless

The error in verbs regarding to relates to the verb agreement where the subject of a sentence would influence the verb form. Example 1.1 shows addition errors of inflectional suffixes in showing present tense. the subject did not need verb attached to suffix $-\mathrm{s}$-es. In here, the student made an utterance of something that should not be written in verb. Misformation occurred in example 1.2 where the student put wrong inflectional suffixes in order to show passive voice. Instead of using suffix -ed, the student should be aware that word teach is irregular verb, so it has its own change (taught) to show participle in order to complete the sentence. Next omission occurred in example 1.3 where the student forgot to add inflectional suffix -ing to show continuous tense. It should be it's really helping us in communication. Example 1.4 shows another misformation. The student should not change root word information becomes informations using suffix $-\mathrm{s}$ es in order to show plurality. Word information itself may contain one or more information. Users in example 1.5 here should be attached with suffix -" to show possession. So, the student forgot to use inflectional suffix to indicate possessive considered as omission error.

The derivational suffixes errors were divided into four classifications. These errors that were made by the students can be seen in Table 3 .

\begin{tabular}{|c|c|c|c|}
\hline No & $\begin{array}{c}\text { Sub- } \\
\text { Indicators }\end{array}$ & Affixes & $\begin{array}{l}\text { Numbers } \\
\text { of Errors }\end{array}$ \\
\hline \multirow[t]{5}{*}{1} & Nouns & -ing & 77 \\
\hline & & -ion & 3 \\
\hline & & -ness & 2 \\
\hline & & -ance & 1 \\
\hline & & -ment & 2 \\
\hline \multirow[t]{5}{*}{2} & Adjectives & -ic & 2 \\
\hline & & -ent & 1 \\
\hline & & -ful & 2 \\
\hline & & -able & 1 \\
\hline & & -ism & 1 \\
\hline \multirow[t]{2}{*}{3} & Adverbs & $-1 y$ & 1 \\
\hline & Total & & 93 \\
\hline
\end{tabular}

Second, errors of derivational suffixes occurred in addition, omission, and misformation. The examples are provided below. 
2.1. The developing is not only coming to the tools..

2.2. Social networking sites make them cannot come out from their comfortable zone.

2.3. It will bring the person to mentally down

From example 2.1, in spite of showing continuous tense, suffix -ing can also be used to derive a noun. Social networking here was used as noun phrase, where social was an adjective and networking was the noun. From the whole sentence, it is assumed what he/she should have written was social network. Phrase social networking contains meaning of of the relationship among individuals and groups, while social network contains meaning of the application or software related to the social media. The correction for this addition error was by deleting the suffix -ing since the message that wanted to be delivered by the student was not clear. Addition errors occurred in example 2.2. The student wrote Social networking sites make them cannot come out from their comfortable zone. The word comfortable that was affixed by suffx -able to was not appropriately used. The correct form to complete the meaning the sentence was comfort zone. In example 2.3, it is assumed that the student intended to write something about mental break down. So the correction of this adverb (mentally) derived from noun (mental) was It will bring the person to mental break down. So the suffix -ly was not needed in this sentence. To correct this error, the sentence was also needed to be transformed.

The errors found more in the inflectional suffixes rather than derivational suffixes. It is based on the theory by Carstairs \& McCarty (2002) that stated most affixes used are inflection affixes and this kind of affixes is part of suffixes. Inflectional affixes are bound morphemes which carry grammatical meaning like "plural", "present tense", or "passive voice". Most of hortatory exposition essay used by students in their writing are suffixes showing plurality, simple present tense, and passive voice

To sum up, it could be concluded that inflectional suffixes involved some components. It means the students' errors in using inflection suffixes influenced grammatical features of hortatory exposition essay. So, the errors in derivational prefixes relate to wrong use of to be and create bad grammatical order of a sentence.

Derivational suffixes attached at the end of a root involved some components. It means the students errors in using derivational suffixes influenced word formation or vocabulary chosen by students in writing hortatory exposition essay. So, the errors in derivational prefixes can lead to bad structure of sentence due to the vocabulary chosen.

The interesting point in affixation made by students was the writing pattern that shows language feature of hortatory exposition based on their prior knowledge. It means they could just simply avoid making affixation or adding affixes that they are commonly having problem with in their essays. For example, most students rarely use social network or social media to replace phrase social networking sites. It happens because they simply repeat the topic from the lecturer debating about "should social networking sites be banned?" However, when using phrase social networking sites that refers to Instagram, Facebook etc, the students usually write social networking which refers to relationship with others not the application or the program. Here students as writers can self-regulate and make word-level, sentence-level, and text-level decisions about the meaning they wish to communicate (Northey et al, 2015). As seen in one student, he/she repeatedly used social networking to replace term social networking sites. Both terms definitely have different meaning. So, this student made errors in addition for word "networking" that she should have reduced suffix "-ing" and make it a simple phrase between adjective "social" and noun "network".

\section{CONCLUSION}

Based on the finding, error analysis in affixation made by English Education Department at Universitas Negeri Padang are various. Affixation errors include inflection and derivation in suffixes. Most affixation errors done by the students were in the use of inflectional suffixes. The errors include 196 inflectional suffixes and 93 derivational suffixes.

It was also found that affixation contributes to the writing. As the students committed errors in their writing, the message of the sentence could not delivered well. In accordance with the results, teacher should give explicit instruction and then gradually the learners can apply their morphological awareness automatically when faced with the needs of using vocabulary or make sentence grammatically.

\section{ACKNOWLEDGMENTS}

I would like to extend my profound gratitude to all of my friends for encouraging me to publish this paper. I would also thank Mrs. Hermawati Syarif and Mr. Hamzah for proofreading and editing this work. Many thanks also go to my father; Mr. Mawardi Nur, my siblings; Meizi M. Nur Putra,Vicky Putra, and Vely Putri for their unflinching support, and special thanks to special woman in my life, my mother; Mrs. Nurmawan thank you that it was through her motivational words that encouraged me to come out with this research work.

\section{REFERENCES}

[1] Bowers, Peter, N., and Cooke, Gina. (2012). Morphology and the Common Core Building Students' Understanding of the Written Word. Perspective on Language and Literacy, 31-35

[2] Carstairs, A. and M.C. Carthy. (2002). An Introduction to English Morphology. Edinburgh: University Press.

[3] Hogue, Ann. (2003). The Essentials of English. New York: Pearson Education, Inc.

[4] Plag, Ingo. (2003). Word Formation in English. Cambridge: Cambridge University Press. 